\title{
Impact of Supercritical Drying with Excess Solvent on Textural Properties of Ti-HMS Catalyst Support
}

\author{
Dragana Prokić-Vidojević ${ }^{1)}$ \\ Sandra Glišićc ${ }^{2}$ \\ Aleksandar Orlovic ${ }^{2)}$
}

\begin{abstract}
Textural characteristics of catalysts and catalysts supports are of a prime importance when it comes to their application in processing of high molecular weight compounds. Drying procedure is a key factor in preservation of wet gel properties. Hexagonal mesoporous silicas (HMS) doped with Ti-ions is finding a promising usage as heterogeneous catalysts support. In this paper, the effect of supercritical drying with excess solvent on the textural characteristics of Ti- HMS is addressed. HMS with $\mathrm{Ti}$ ions ( $\mathrm{Si} / \mathrm{Ti}$ atomic ratio of 40 ) is prepared using the sol-gel method. Dodecylamine is used as the structure directing surfactant $(S)$ and TEOS and Titanium butoxide as the inorganic precursors $(I)$. Specific surface area, mesoporosity and pore volume of the support dried by thermal evaporation of solvent in air and dried in excess of supercritical ethanol are compared. The results indicate that improved specific surface area and almost four times bigger value for mesopore volume are obtained using supercritical drying procedure.
\end{abstract}

Key words: catalysts, mesoporous catalysts, sol-gel method, drying method, petroleum fractions.

\section{Introduction}

$I_{a}^{\mathrm{N}}$ $\mathrm{N}$ recent years, porous materials have found their application as heterogeneous catalysts and catalysts supports for numerous petroleum processes $[1,2]$. The most widely used are zeolites, microporous crystals with a narrow pore size distribution and average pore diameter less than $2 \mathrm{~nm}$. However, small pores sizes become an important obstacle when large, bulky molecules need to be processed. Their diffusion inside the pores is limited and therefore active sights within the pores become unavailable. In the last decades, much research is focused on catalysts pore size enlargement from micropore to mesopore range, while retaining narrow size distribution. Accordingly, new family of ordered mesoporous materials aroused. It is believed that they will improve some commercial processes in the future, by superseding zeolites and amorphous silica-alumina catalysts [2].

The first ordered mesoporous material was synthesized by the scientists from the Mobil Oil Research and Development. Moreover, they were the first to explain and recognize extraordinary properties of this material [3]. Using cationic surfactants as a template to assemble silicate anions from solution, three members of the Mobil Composition of Matter (denoted as MCM) were reported: MCM-41 with hexagonal array of uniform pores, MCM-48 with cubic and MCM-50 with lamellar mesostructure [4]. This discovery was a breakthrough in engineering of materials and accelerated progress of new mesoporous silicas [5]. In order to improve the template removal from the pores and lessen pore blockage, Zhang et al. [6] and Pauly et al. [7] have developed additional approach for the preparation of the mesoporous silica. It was based on neutral templating mechanism. They have used primary amines as a neutral surfactant to synthesize
HMS (hexagonal mesoporous silica). In this case, H-bonding was the driving force for the structure formation and therefore surfactant extraction is easier and almost complete. Tanev et al. [8] have compared physical properties of MCM-41 and HMS and found similarities in high values of surface areas (around $700-1000 \mathrm{~m}^{2} / \mathrm{g}$ ) and pore volumes. These are important advantages for using these materials in catalysis, since a high surface area allows high concentrations of active sights. Another advantage that HMS silica possesses is a thick framework wall which contributes to superior thermal stability required for the catalytic applications.

Some research in the application of MCM-41 and HMS in hydrotreating reactions has been done recently. Corma et al. $[9,10]$ tested NiMo/MCM-41 for hydrodesulphurization, hydrodenitrogation and hydrocracking reactions and reported better activity in comparison with other supports- amorphous silica-alumina and USY zeolite. Montesinos-Castellanos et al. [11] modified HMS with the incorporation of heteroatoms within their framework and reported that the presence of Al, $\mathrm{Ti}$ and $\mathrm{Zr}$ ions increased the hydrogenation ability of NiMo catalysts in the reaction of naphthalene. Similar conclusion made Halachev et al. [12] for NiW/(P)Ti-HMS catalyst. Zepeda et al. $[13,14]$ stated increased pore diameter with $\mathrm{Ti}$ incorporation, as a result of a higher bond length of Si-O-Ti than $\mathrm{Si}-\mathrm{O}-\mathrm{Si}$ length. Numerous studies made with the conventional active metals CoMo, NiMo, CoW, NiW supported on Al-, Ti-HMS [13-16] claim enhanced HDT activity with these supports.

The crucial advantage for catalytic application of these materials is heteroatoms incorporation, and development of the appropriate surface acid sights [17]. Homogeneity at the molecular scale influences the acidic properties [18-20].

\footnotetext{
1) Military Technical Institute (VTI), Ratka Resanovića 1, 11132 Belgrade, SERBIA

2) University of Belgrade, Faculty of Technology and Metallurgy, Karnegijeva 4, 11000 Belgrade, SERBIA

Correspondence to: Dragana Prokić-Vidojević; e-mail: drprokic@yahoo.co.uk
} 
Therefore, the choice of the preparation method is important. Conventional syntheses procedures, like precipitation and coprecipitation methods, are very limeted in fine controling of component mixing because of the differences in the $\mathrm{pHs}$ and rates of hydroxides precipitation $[21,22]$. On the other hand, the sol-gel process allows homogeneous formation of heterolinkages even at low temperatures [17, 23, 24]. Toba et al. $[25,26]$ examined titania-silica and titania-alumina xerogels made by coprecipitation and sol-gel method and found higher acidity in the sol-gel samples attributed to a higher density of hetero-linkages formed. Also, the surface area found in titania-alumina sample was considerably larger in sol-gel sample.

In view of the fact that HMS silica is synthesized using solgel procedure and solvent needs to be removed prior to calcination, the applied drying procedure is the key factor in determining the textural characteristics. The most frequently used drying procedure - thermal evaporative drying in air causes the formation of capillary pressures at the liquid-vapor interface, reaching values of up to 100-200 MPa [27] and therefore could cause structural collapse and reduction of mesoporosity [28, 29]. Obtained xerogels contain significant fraction of micropores and reduced surface areas. In order to overcome that problem, some researchers have tried to age the gel in the silane precursor, alcohol or water bath and in that way increase the network stiffness prior to drying [30-32]. In contrast, an aerogel is a gel from which the liquid has been removed in such a way as to prevent significant collapse or change in the structure as liquid is removed. This is typically accomplished by heating the liquid-filled gel in an autoclave while maintaining the prevailing pressure above the vapor pressure of the liquid until the critical temperature of the liquid has been exceeded, and then gradually releasing the vapor, usually by gradually reducing the pressure either incrementally or continuously, while maintaining the temperature above the critical temperature. The critical temperature is the temperature above which it is impossible to liquefy a gas, regardless of how much pressure is applied. At temperatures above the critical temperature, the distinction between liquid and gas phases disappears and so do the physical manifestations of the gas/liquid interface. In the absence of an interface between liquid and gas phases, there is no surface tension and hence no surface tension forces to collapse the gel. Such a process is called "supercritical drying in excess solvent." Aerogels produced by supercritical drying typically have high porosities (50-99 vol\%), lower microporosity, higher surface areas and gives amorphous mixed oxide aerogels [33-41]. Calvino et al. [42] examined the influence of the way of drying on textural characteristics of $10 \%$ titania - $90 \%$ silica and found the following order for the surface areas: $459 \mathrm{~m}^{2} / \mathrm{g}$ for xerogel, $515 \mathrm{~m}^{2} / \mathrm{g}$ for alcogel (supercritical drying with $\mathrm{CO}_{2}$ at $315 \mathrm{~K}$ ) and $832 \mathrm{~m}^{2} / \mathrm{g}$ for aerogel (supercritical drying in alcohol at $600 \mathrm{~K}$ ). Brodsky et al. $[43,44]$ reported higher average pore diameter observed in titania-silica aerogels and alcogels with the higher supercritical drying temperature.

The objective of this work is to investigate the influence of supercritical drying with excess solvent procedure on textural characteristics of Ti-HMS supports. Two Ti-HMS supports were synthesized. One was dried by a thermal evaporation in air, and the other was dried in excess of SC ethanol.

\section{Experimental part}

\section{Materials}

Ti-substituted mesoporous silicas were synthesized using tetraethyl ortosilicate (TEOS, Aldrich 98\%) and titanium butoxide (Ti-but, Aldrich 97\%) as inorganic precursors. Surface directing agent was dodecylamine $\left(\mathrm{C}_{12} \mathrm{H}_{25} \mathrm{NH}_{2}\right.$, DDA, Aldrich 98\%).

\section{Preparation of the catalyst supports}

In order to examine the influence of the drying process on textural characteristics, two different Ti-HMS supports were synthesized. The procedure for the synthesis of pure hexagonal mesoporous silica (HMS) was first proposed by Tanev and Pinnavaia $[7,8]$. It was based on the neutral $\mathrm{S}^{\circ} \mathrm{I}^{\circ}$ templating route and $\mathrm{H}$-bonding between neutral inorganic precursor $\left(\mathrm{I}^{\circ}\right)$ and neutral primary amine $\left(\mathrm{S}^{\circ}\right)$ as a surface directing agent. The incorporation of the Ti heteroatom was done following the procedure published by Gontier and Tuel [45]. The molar composition of the reaction mixture was: 0.1TEOS:0.025Ti-but: 0.65EtOH:0. 1isopropyl alcohol: 0.027DDA: $3.6 \mathrm{H} 2 \mathrm{O}: 0.002 \mathrm{HCl}$. Basically, the first solution (A) was obtained by mixing TEOS, Ti-but, EtOH and isopropyl alcohol. The second solution (B) was dissolved DDA in water and $\mathrm{HCl}$. Solution A was slowly added to solution B while vigorously stirred and the stirring was maintained for half an hour. The reaction products were aged at ambient temperature for 1.5 hours, filtered under vacuum and washed several times with ethanol (with total ethanol amount of $100 \mathrm{ml}$ ). Two catalyst supports were obtained using this mixture in the following way: one support, aerogel, was dry in excess of supercritical ethanol on 100 bars and 528 $\mathrm{K}$ for half an hour and another, xerogel, was dried at room temperature for 24 hours. Subsequently, both samples were calcined in air at $823 \mathrm{~K}$ for $4 \mathrm{~h}$, with heating rate of 2.5 $\mathrm{K} / \mathrm{min}$, being held for a half an hour on $823 \mathrm{~K}$.

\section{Supercritical drying in excess of solvent}

Catalyst support, prepared by previously described procedure, was transferred to the pressure vessel (Autoclave Engineers BTRS-Jr, Division of Snap-title, Inc., Erie, PA, USA) and the vessel was filled with additional $170 \mathrm{ml}$ of ethanol. Such a procedure was necessary to ensure that the pores in the obtained material were always filled with single phase ethanol (liquid, supercritical or gas) thereby avoiding formation of the two phase region (liquid-gas) in the pores $[46,47,48]$. The vessel was then sealed and heated (heating rate $3.3 \mathrm{C} \% \mathrm{~min}$, total time of heating was $70 \mathrm{~min}$ ) to the desired temperature and pressure of 100 bars and $528 \mathrm{~K}$. Upon the reaction completion, after half an hour, the system was depressurized to atmospheric pressure followed by gradual temperature decrease to ambient conditions.

\section{Characterization of the samples}

Textural parameters were estimated using $\mathrm{N}_{2}$ adsorptiondesorption isotherms recorded at $77 \mathrm{~K}$ on Thermo Finnigan Sorptomatic 1990. The samples were degassed in vacuum prior to the analysis, at $373 \mathrm{~K}$ for $2 \mathrm{~h}$ and subsequently at 473 $\mathrm{K}$ for $16 \mathrm{~h}$. Specific surface area was calculated by applying BET equation to the range of relative pressures from 0.05 to 0.16 . The t-plot analysis was another method used to evaluate textural properties of the samples. This method is frequently used for the characterization of porous materials. The average pore diameter and mesopore volume were calculated using the Barret-Joyner-Halenda method $(\mathrm{BJH})$ to the desorption branch of isotherm and the Dollimore and Heal model to the adsorption branch. The cumulative pore volume was obtained using the Gurvich model. The assessments of microporosity were made using the Dubinin and Raduskevich correlation.

The Ti-ion incorporation in all four supports was conformed on FT-IR spectrophotometer, Thermo, Nicolet iS10, with ATR, operating in wavelength range from 4000 $\mathrm{cm}-1$ to $600 \mathrm{~cm}-1$. 
The substrate and catalysts morphology and $\mathrm{Ti}$ concentration was determined by Scanning Electron Microscope (SEM) JEOL JSM-6610 LV, equipped with an Energy Dispersive X-ray Spectrometer (EDS) Oxford X-Max. To reduce charging effect, the samples were coated with a thin $(5 \mathrm{~nm})$ conducting layer of gold. An electron microprobe used in an energy dispersive mode (EDX) was employed to obtain information on the titanium dispersion in the samples.

\section{Results and discussion}

\section{FT-IR spectroscopy of calcined supports}

Ti-O-Si bonds formation was determined by IR spectroscopy. The IR spectra of four catalyst supports are shown in Fig.1.
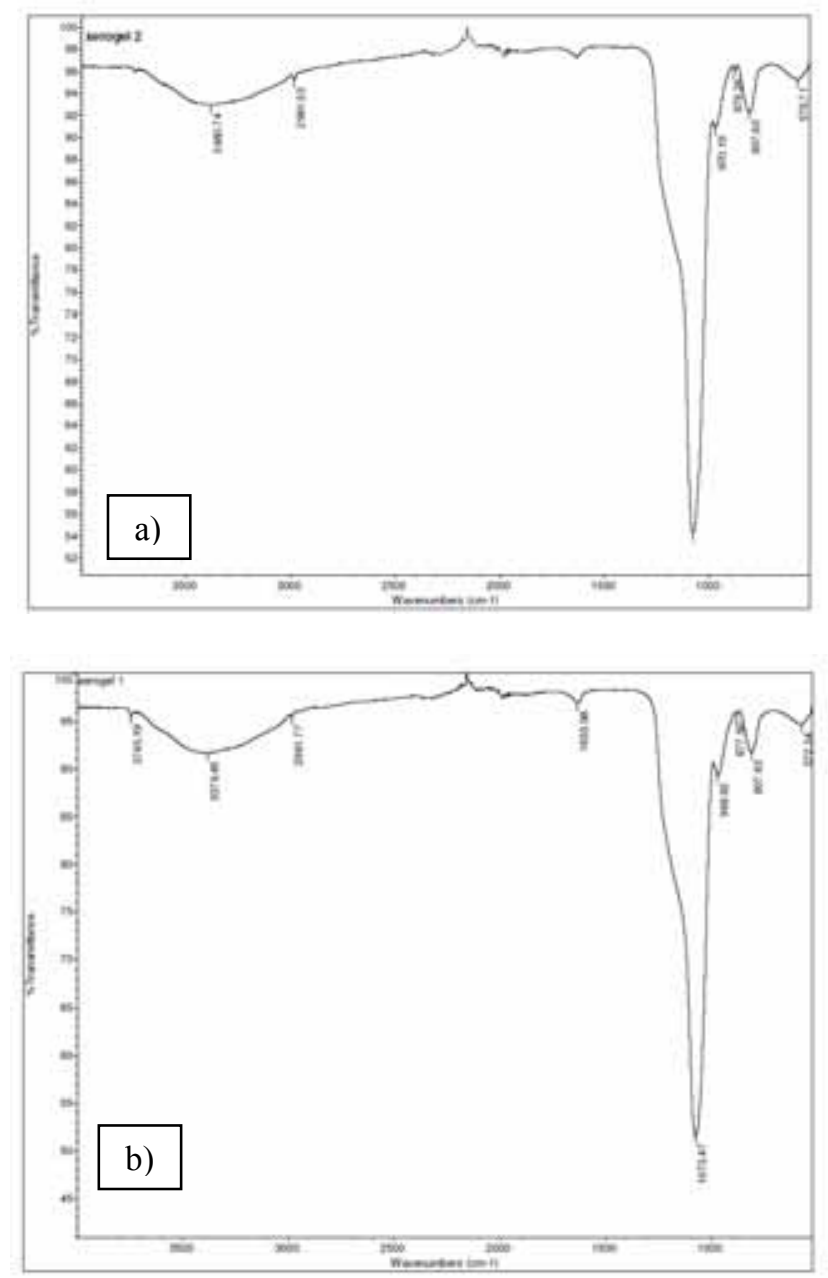

Figure 1. FT-IR images of Ti-HMS supports: a) dried by thermal evaporation in air, b) dried with SC solvent excess.

The asymmetric vibration of $\mathrm{Si}-\mathrm{O}-\mathrm{Si}$ bond shows band at $1087 \mathrm{~cm}-1$ and its shift to lower wavenumbers is observed when Ti-ions are incorporated into the HMS structure [49]. This band is positioned at ca. $1073 \mathrm{~cm}-1$ for all four measured supports. Moreover, the literature reports that the IR band appearing in the region from 910 to $970 \mathrm{~cm}-1$ is a characteristic vibration caused by the formation of Ti-O-Si bonds [50, 51]. Its exact position depends on chemical composition of the sample and the instrument characteristics. According to that, the band at ca. $970 \mathrm{~cm}-1$ found in all four samples can be assigned to the stretching vibration of $v_{\text {as }}(\mathrm{Si}-\mathrm{O}-\mathrm{Ti})$ group. However, this is not a definite proof, since Ti-free silicates also exhibit similar band. Therefore, it is necessary to compare its intensity to the intensity of the band at ca. $802 \mathrm{~cm}-1$, indication of symmetric stretching vibration of $v_{\mathrm{s}}(\mathrm{Si}-\mathrm{O}-\mathrm{Si})[52]$. When the intensity of the band at ca. $970 \mathrm{~cm}-1$ is enhanced compared to the intensity of the band at ca. $802 \mathrm{~cm}-1$, then this can be taken as an indication of Ti-ions incorporation [53]. This enhancement can be seen in Fig.1. The more enhanced it is, the more Ti-O-Si linkages are formed.

Furthermore, hydrogen bonding between silanol groups is displayed by the broad band at ca. $3380 \mathrm{~cm}^{-1}$. This band, found in the hydroxyl region, is an indication of $v_{\mathrm{OH}}(\mathrm{Si}-\mathrm{O}-\mathrm{H})$ vibration. In the pure silicates, it is usually found at higher wavelenght, ca. $3445 \mathrm{~cm}^{-1}$. This shift reveals more hydrogen bonding with $\mathrm{Ti}$ incorporation caused by the existance of defective sites.

\section{$\mathrm{N}_{2}$ adsorption-desorption isotherms}

The physical adsorption-desorption isotherms of nitrogen was used to determine the textural properties of the supports and recorded isotherms are shown in Fig.2.

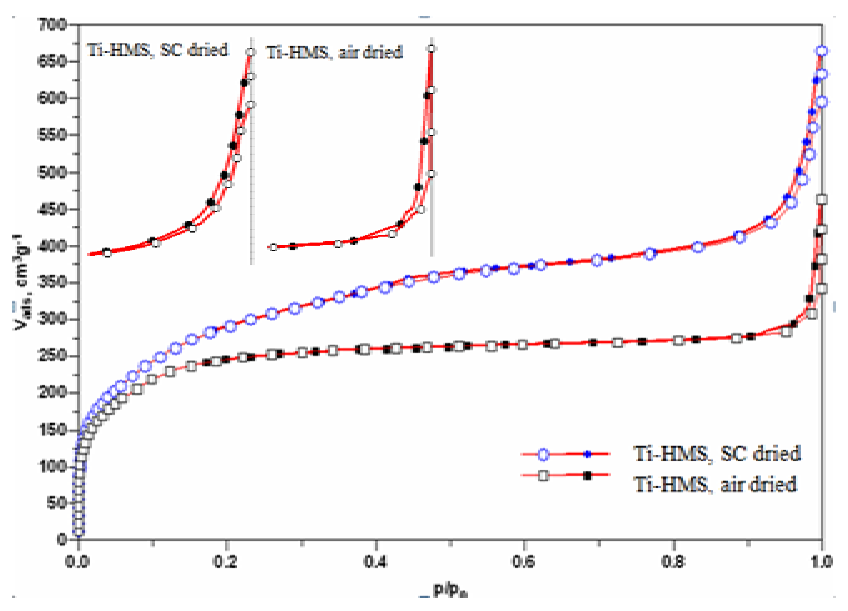

Figure 2: Comparison of $\mathrm{N}_{2}$ adsorption-desorption isotherms of Ti-HMS support dried in excess of supercritical ethanol and the support dried by thermal evaporation in air

From Fig.2 it can be seen that the isotherms of the supercritically dried material resemble more IUPAC type IV isotherms [54], expected for mesoporous silicas. It is also seen that the aforementioned support has adsorbed much more nitrogen than support dried by thermal evaporation for the same relative pressures. That is the indication of a higher specific surface area and bigger total pore volume obtained, as it is evidenced by the results given in Table 1. Moreover, the sharp nitrogen uptake at low relative pressures, found for both samples, indicate a well developed micropore region, which also added to valued to high surface area obtained. Another increase in the relative pressures range of $\mathrm{p} / \mathrm{p}_{0}=0.2$ to 0.5 , more pronounced for SC dried support, results from better developed mesopores region and therefore capillary condensation of nitrogen inside the pores occur [55]. Shift of framework confined mesopores filling to higher relative pressures found with this support indicates an increase in framework pore size, as well. Moreover, at high relative pressures, bigger than 0.9 , both samples had significant uptake of $\mathrm{N}_{2}$, characteristic for the materials containing mesopores at the upper limit of mesoporosity [53]. Both hysteresis loops close at relative pressures above 0.85 , have narrow shape with almost parallel adsorption and desorption branches, confirming the existence of larger mesopores.

In order to make a quantitative comparison of drying procedure influence on the textural parameters, calculated values, such as specific surface area derived from both BET equation and t-plot analysis, $\mathrm{S}$, cumulative pore volume obtained using the Gurvich model, $\mathrm{V}_{\mathrm{p}}$, volume of the mesopores calculated using $\mathrm{BJH}$ and Dollimore and Heal correlation, $\mathrm{V}_{p}$, meso and average pore diameters $\mathrm{D}_{\mathrm{p} \text {,avg. }}$ of the 
supports are given in Table 1.

Table 1. Textural parameters of Ti-HMS supports.

\begin{tabular}{|c|c|c||}
\hline Sample & $\begin{array}{c}\text { Ti-HMS, thermally } \\
\text { evaporated in air }\end{array}$ & $\begin{array}{c}\text { Ti-HMS, } \\
\text { SC dried }\end{array}$ \\
\hline \hline $\mathrm{S}_{\mathrm{BET}}, \mathrm{m}^{2} / \mathrm{g}$ & 868 & 1100 \\
\hline $\mathrm{S}_{\mathrm{t}-\mathrm{plot}, \mathrm{m}^{2} / \mathrm{g}}$ & 851 & 1015 \\
\hline${ }^{\mathrm{a}} \mathrm{V}_{\mathrm{p}}, \mathrm{cm}^{3} / \mathrm{g}$ & 0.471 & 0.790 \\
\hline${ }^{\mathrm{b}} \mathrm{V}_{\mathrm{p}, \mathrm{meso},(\mathrm{BJH})} \mathrm{cm}^{3} / \mathrm{g}$ & 0.116 & 0.495 \\
\hline${ }^{\mathrm{c}} \mathrm{V}_{\mathrm{p}, \text { meso,(DH) }} \mathrm{cm}^{3} / \mathrm{g}$ & 0.143 & 0.422 \\
\hline${ }^{\mathrm{b}} \mathrm{D}_{\mathrm{p}, \text { avg,(BJH) }} \mathrm{nm}$ & 3.93 & 4.33 \\
\hline${ }^{\mathrm{c}} \mathrm{D}_{\mathrm{p}, \text { avg, (DH) }} \mathrm{nm}$ & 3.66 & 6.34 \\
\hline
\end{tabular}

${ }^{a}$ Calculated by Gurvich model, at $\mathrm{p} / \mathrm{p}_{0}=0.98$.

${ }^{\mathrm{b}}$ Calculated by BJH model.

${ }^{\mathrm{c}}$ Calculated by Dollimore and Heal model.

BET surface areas found for both supports have high values, bigger than $850 \mathrm{~m}^{2} / \mathrm{g}$. Very similar values for total surface areas resulted from the t-plot analyses with tparameter in the range of 0.13 to $0.25 \mathrm{~nm}$. These results show that the surface area is improved by a factor of 1.26 and total pore volume by a factor of 1.6 with supercritical drying. Mesopore volumes found for thermally evaporated support are $0.116 \mathrm{~cm}^{3} / \mathrm{g}$ and $0.143 \mathrm{~cm}^{3} / \mathrm{g}$, depending on the model used for calculation. Values for SC dried sample are 0.495 $\mathrm{cm}^{3} / \mathrm{g}$ and $0.422 \mathrm{~cm}^{3} / \mathrm{g}$. Mesopore volume in thermally evaporated sample accounts for $25 \%$ of total pore volume while in SC sample it is enhanced to $63 \%$. Almost four times bigger value for mesopore volume is obtained with SC dried sample. Such a strong improvement is a result of preserved wet gel structure while SC drying. Actually, as the esterification reactions take place during high temperature $\mathrm{SC}$ drying with ethanol, the surface $\mathrm{Si}-\mathrm{OH}$ group are modified into hydrophobic Si-OR groups. Moreover, the excess of ethanol prevents solvent evaporation inside the pores during initial heating in the autoclave, and shrinkage of gel before SC conditions are reached. Consequently, specific surface area and pore volume increase.

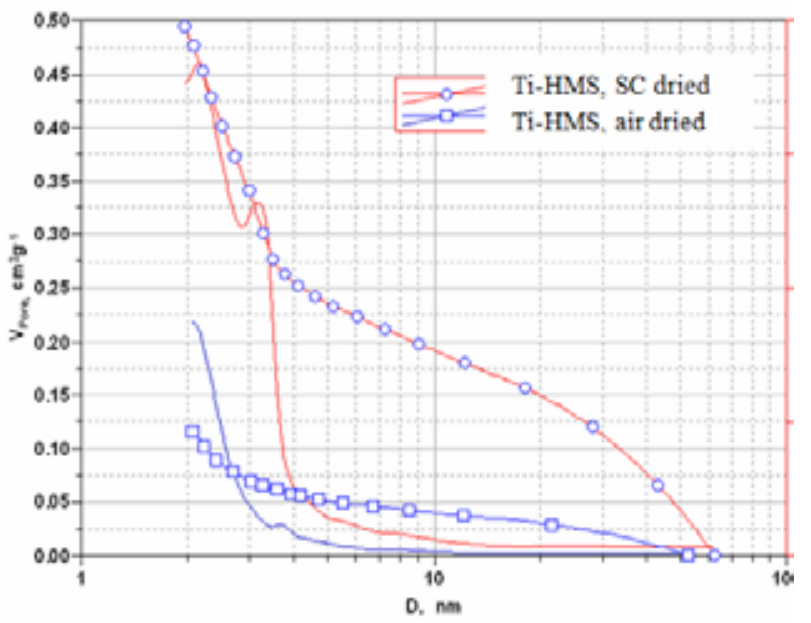

Figure 3. Comparison of cumulative pore volume in the mesopore region of Ti-HMS support dried in excess of supercritical ethanol and the support dried by thermal evaporation in air.

Graphical comparison of mesopore region of both samples is given in Fig.3. Better preserved mesoporosity with CS drying is clearly visible. Furthermore, mean pore diameter is enhanced from 3.93 to $4.33 \mathrm{~nm}$. Both these values are higher than previously reported results of Gontier at al. [45] for pure silica materials. This is expected since titanium cations have radius larger than $\mathrm{Si}^{4+}$ cations, so the length of $\mathrm{Si}-\mathrm{O}-\mathrm{Ti}$ bond is bigger than $\mathrm{Si}-\mathrm{O}-\mathrm{Si}$ bond.

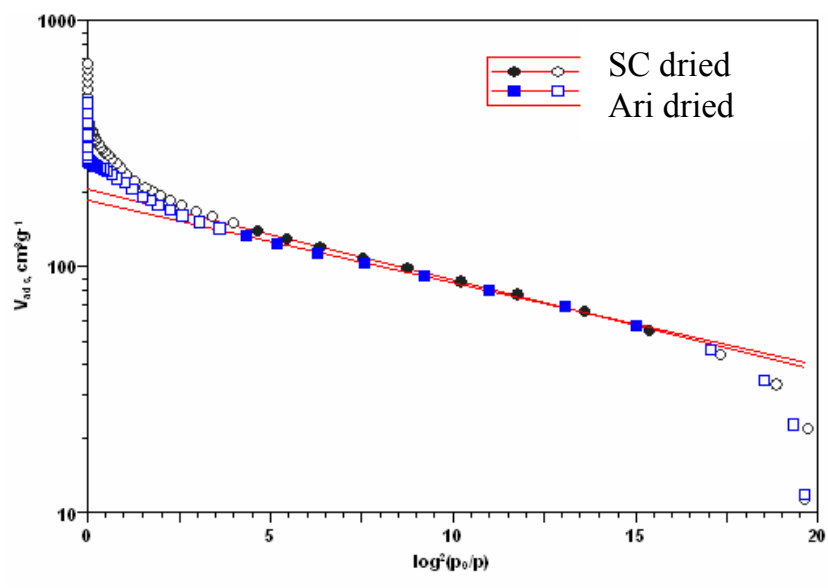

Figures 4. Dubinin and Raduskevich graphs used for micropore volume calculation of two supports.

The textural parameters of micropore region are analyzed using correlation of Dubinin and Raduskevich. The obtained graphs are given in Fig.4, and calculated results are presented in Table 2.

Table 2: Micropore volume and fraction of two supports calculated using Dubinin and Raduskevich correlation.

\begin{tabular}{|c|c|c|}
\hline Sample & $\begin{array}{c}\text { Ti-HMS, thermally } \\
\text { evaporated in air }\end{array}$ & Ti-HMS, SC dried \\
\hline \hline $\mathrm{V}_{\mathrm{p}, \text { micro }} \mathrm{cm}^{3} / \mathrm{g}$ & 0.287 & 0.320 \\
\hline Micropore fraction, $\%$ & 60 & 40 \\
\hline
\end{tabular}

The results from Table 2 reveal a reduction in micropores volume fraction in total pore volume from $60 \%$ to $40 \%$ using $\mathrm{SC}$ drying procedure. This confirms that the pressures evolved in mesopores during phase transformation from liquid to gas state while thermal evaporation of the solvent caused the gelnetwork shrinkage and mesopores volume reduction in favor of micropores.

\section{SEM-EDS analyses of catalyst supports}

SEM-EDS analyses were used to examine the morphology of the particles and the homogeneity of the Ti distribution in the HMS framework.

In Fig.5 the SEM images of the studied samples are presented. These micrographs show that Ti-HMS is comprised of sphere-shaped particles, smaller than $1 \mu \mathrm{m}$ in diameter. This is in accordance with the previous findings of other authors [55]. These particles are organized in nonuniform agglomerates. Comparing the particle sizes of the prepared supports indicates that the particles of support dried using excess of SC solvent are smaller in diameter, providing material with much finer morphology. This correlates to a higher specific surface area value obtained from the adsorption measurements. Also, this should influence the increase of textural mesoporosity, which does not arise from the framework pore volume, but from the interparticle voids.

Appropriate titanium dispersion is important for generation of acid sights in the support. Sol-gel method provides superior mixing at the molecular level and homogeneous formation of heterolinkages. Moreover, the average bond angle of Ti-O-Ti is $159^{\circ}$ and of $\mathrm{Si}-\mathrm{O}-\mathrm{Si}$ is $152^{\circ}$; the average bond lengths are $1.8 \AA$ for $\mathrm{Ti}-\mathrm{O}$ and $1.6 \AA$ for $\mathrm{Si}-\mathrm{O}$. These similar structural properties and low $\mathrm{Ti}$ content in the samples allow homogeneous substitution of $\mathrm{Si}$ for $\mathrm{Ti}$ in the silica matrix. However, some reports from the literature suggest that the wet gel structure and intimate mixing would not be preserved during supercritical drying with alcohol, so called high temperature drying, because the segregation of anatase occurs [56]. On the contrary, SEM-EDS of our samples, shown in 


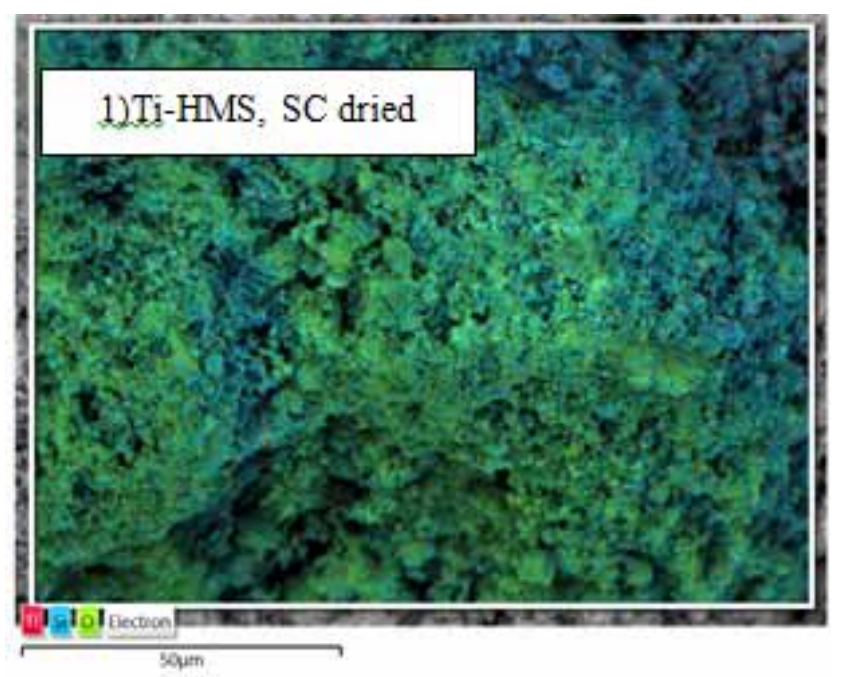

Figure 6. SEM-EDS images of Ti dispersion in supports

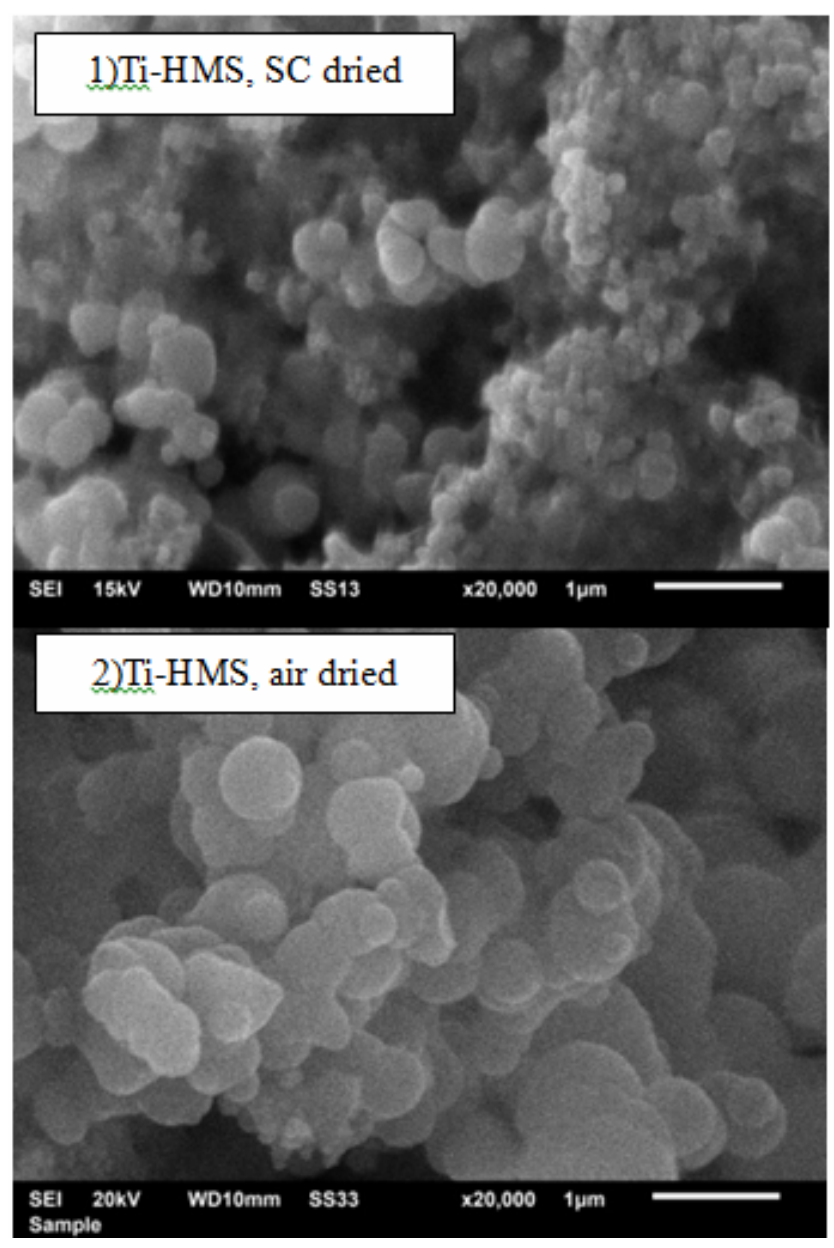

Figure 5. SEM images of calcined supports

Fig.6, reveal good $\mathrm{Ti}$ dispersion in both samples without observed anatase formation on the surface.

\section{Concluding remarks}

In the present work influence of drying procedure on textural characteristics of two Ti-HMS supports has been reported. The mesopores formation is obtained using dodecylamine as a structure directing agent. In polar solvent, DDA forms rodlike micels with hydrofobic tail oriented toward the center of the micel, and hidriphillic headgroup toward the micel/solvent interface.
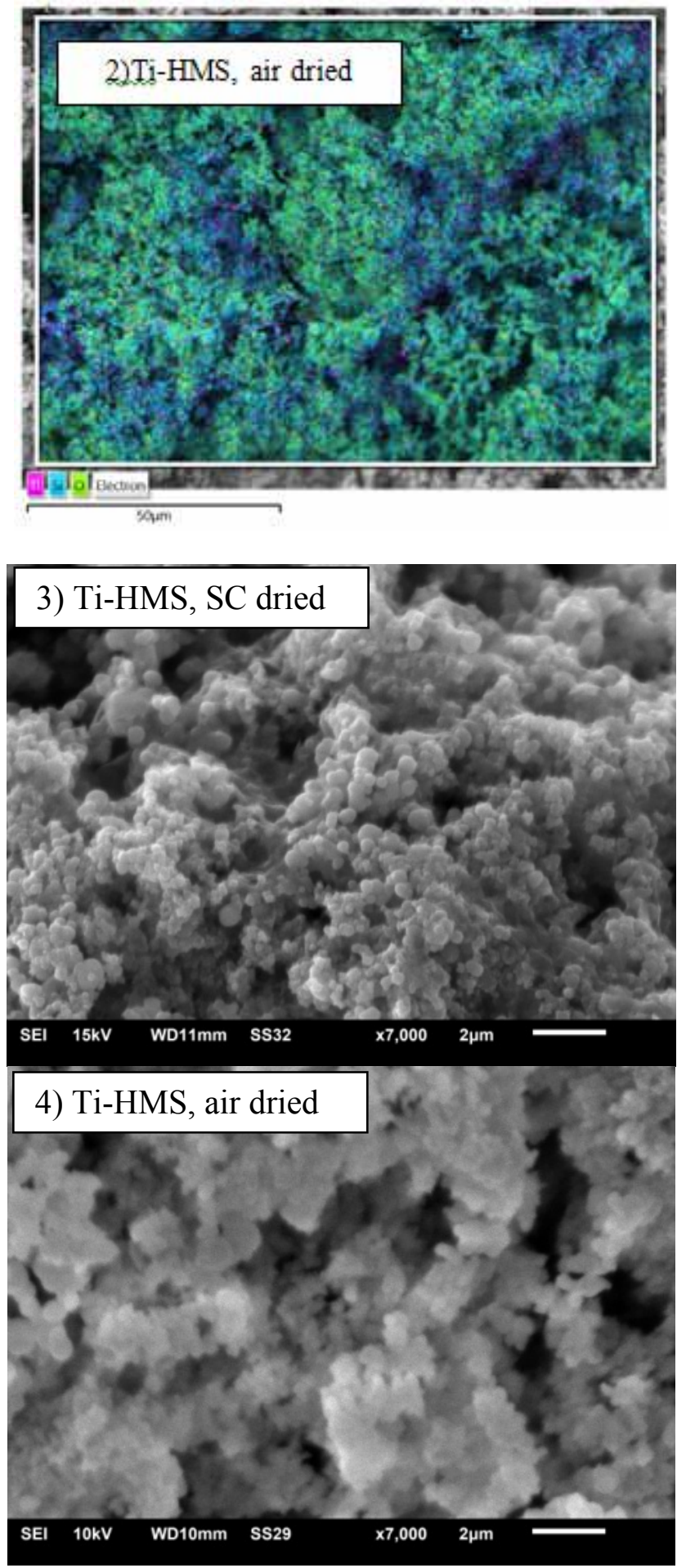

The formation of mesostructure occurs via H-bonding interactions of precursors silanol hydrogens and electron pairs of the surfactant headgroups. The results for textural characteristics derived from nitrogen adsorption-desorption isotherms show significant improvement in mesopore volume and specific surface area of the support dried with supercritical solvent excess. Material with almost four times bigger mesopore volume is obtained with a supercritical process and with a much finer morphology. The formation of Ti-O-Si linkages is conformed with FT-IR spectroscopy, while the appropriate Ti dispersion is observed using SEM-EDS.

\section{References:}

[1] TAGUCHI,A., SCHUTH,F.: Oredered Mesoporous Materials in Catalysis, Micropor. Mesopor. Mater., 2005, Vol.77, pp.20-29. 
[2] GURAV,J.L., JUNG,I.K., PARK,H.H., KANG,E.S., NADARGI,D.Y.: Silica aerogel: synthesis and applications, J. of Nanomater. 2010, pp. $1-11$.

[3] BECK,J.S., CHU,C.T.-W, JONSON,I.D., KRESGE,C.T., LEONOWITCH,M.E., ROTH,W.J., VARTULI,J.W., WO Patent 91/11390, 1991.

[4] KRESGE,C.T., LEONOWICZ,M.E., ROTH,W.J., VARTULI,J.W., BECK,J.S.: Ordered mesoporous molecular sieves synthesized by a liquid-crystal template mechanism, Nature, 1992, Vol.359, p.710.

[5] SCHUTH,F.: Non-siliceous Mesostructured and Mesoporous Materials, Chem. Mater., 2001, Vol.13, p.3184.

[6] ZHANG,W., PAULY,T., PINNAVAIA,T.: Tailoring the Framework and Textural Mesopores of HMS Molecular Sieves through an Electrically Neutral Assembly Pathway, Chem. Mater., 1997, Vol.9, pp.2491-2498.

[7] PAULY,T., PINNAVAIA,T.: Pore Size Modification of Mesoporous HMS Molecular Sieve Silicas with Wormhole Framework Structures, Chem. Mater., 2001, Vol.13, pp.987-993.

[8] TANEV, P., PINNAVAIA, T.: Mesoporous Silica Molecular Sieves Prepared by Ionic and Neutral Surfactant Templating: A comparison of Physical Properties, Chem. Mater., 1996, Vol.8, pp. 2068-2079.

[9] CORMA,A., MARTINEZ,A., MARTINEZ-SORIA,V., MONTON,J.B.: Hydrocracking of Vacuum Gasoil on the Novel Mesoporous MCM-41 Aluminosilicate Catalyst, J. Catal., 1995, Vol.153, pp. 25-31.

[10] CORMA,A., MARTINEZ,A., MARTINEZ-SORIA,V.: Hydrogenation of Aromatics in Diesel Fuels on Pt/MCM-41 Catalysts, J. Catal., 1997., Vol. 169, pp.480-489.

[11] MONTESINOS-CASTELLANOS,A., ZEPEDA,T.A.: High hydrogenation performance of the mesoporous $\mathrm{NiMo} / \mathrm{Al}(\mathrm{Ti}, \mathrm{Zr})-\mathrm{HMS}$ catalysts, Micropor. Mesopor. Mater. 2008., Vol.113, pp.146-162.

[12] HALACHEV,T., NAVA,R., DIMITROV,L.D.: Catalytic activity of (P)NiMo/Ti-HMS and (P)NiW/Ti-HMS catalysts in the hydrogenation of naphthalene, Appl. Catal. A: Gen., 1998., Vol.169, pp.111-117.

[13] ZEPEDA,T.A., PAWELEC,B., FIERRO,J.L.G., HALACHEV,T.: Removal of refractory S-containing compounds from liquid fuels on novel bifunctional CoMo/HMS catalysts modified with Ti, Appl. Cat. B: Env., 2007, Vol.71, pp.223-236.

[14] ZEPEDA,T.A., PAWELEC,B., FIERRO,J.L.G., MONTESINOS,A., OLIVAS,A., FUENTES,S., HALACHEV,T.: Synthesis and characterization of P-modified mesoporous $\mathrm{CoMo} / \mathrm{HMS}$-Ti catalysts, Micropor. Mesopor. Mater., 2008., Vol.111, pp. 493-506.

[15] [15]CHIRANJEEVI,T., KUMAR,P., MAITY,S.K., RANA,M.S., MURALI DHAR, G., PRASADA RAO, T.S.R.: Characterization and hydrodesulfurization catalysis on $\mathrm{WS}_{2}$ supported on mesoporous AlHMS material, Microp. Mesop. Mat., 2001, Vol. 44, pp. 547-556.

[16] NAVA,R., MORALES,J., ALONSO,G., ORNELAS,C., PAWELEC,B., FIERRO,J.L.G.: Influence of the preparation method on the activity of phosphate-containing CoMo/HMS catalysts in deep hydrodesulphurization, Appl. Cat. A: General 2007, Vol.321, pp. 5870.

[17] MILLER,J.B., KO,E.I.: Control of mixed oxide textural and acidic properties by the sol-gel method, Cat. Tod. 1997, Vol.35, pp. 269-292.

[18] MILLER,J.B., RANKIN,S.E., KO,E. I.: Strategies in Controlling the Homogeneity of Zirconia-Silica Aerogels: Effect of Preparation on Textural and Catalytic Properties, J. Catal., 1994., Vol.148, pp.673682 .

[19] MILLER,J.B., KO,E.I.: Acidic Properties of Silica-Containing Mixed Oxide Aerogels: Preparation and Characterization of Zirconia-Silica and Comparison to Titania-Silica, J. Catal., 1996, Vol.159, pp. 58-68.

[20] TOBA,M., MIZUKAMI,F., NIWA,S., SANO,T., MAEDA,K., ANNILA,A., KOMPPA,V.: Effect of the type of preparation on the properties of titania/silicas, J. Mol. Catal., 1994, Vol.91 pp. 277-289.

[21] [21] VOGT,E.T.C., BOOT,A., VAN DILLEN,A.J., GEUS,J.W., JANSEN,F.J.J.G., VAN DER KERKOF,F.M.G.: Preparation and performance of a silica-supported $\mathrm{V}_{2} \mathrm{O}_{5}$ on $\mathrm{TiO}_{2}$ catalyst for the selective reduction of $\mathrm{NO}$ with $\mathrm{NH}_{3}$, J. of Catal., 1989, Vol.114, pp. 313-320.

[22] KO,E.I., CHEN,J.P., WEISSMANN J.G.: A study of acidic titania/silica mixed oxides and their use as supports for nickel catalysts, J. of Catal., 1987, Vol.105, pp.511-520.

[23] HANDY,B.E., MACIEJEWSKI,M., BAIKER,A., WOKAUN,A.: Genesis and structural properties of alkoxide-prepared titania-silica xerogels, J.Mater.Chem, 1992, Vol. 2(8), pp.833-840.

[24] NEUMANN,R., CHAVA,M., LEVIN,M.: Hydrogen peroxide oxidations catalysed by metallosilicalite xerogels, J.Chem.Soc.Chem.
Commun., 1993, Vol.22, pp.1685-1687.

[25] TOBA,M., MIZUKAMI,F., NIWA,S., SANO,T., MAEDA,K., ANNILA,A., KOMPPA,V., The effect of preparation methods on the properties of zirconia/silicas, J. Mol. Catal. 1994., Vol. 94, pp.85-96.

[26] TOBA,M., MIZUKAMI,F., NIWA,S., KIYOZUMI,Y., MAEDA,K., ANNILA,A., KOMPPA,V.: Effect of preparation methods on properties of alumina/titania, J. Mater. Chem., 1994, Vol.4(4), pp. 585-589.

[27] SCHERER,G.W., SMITH,D.M.: Cavitation during drying of a gel, Journal of Non-Crystalline Solids, 1995, Vol.189, pp.197-211.

[28] [28]DORCHEH, A.S., ABBASI, M.H.: Silica aerogel: synthesis, properties and characterization, J.of Mater. Proc. Techn., 2008, Vol.199, pp.10-26.

[29] ESTELLA,J., ECHEVERRIA,J.C., LAGUNA,M., GARRIDO,J.J.: Effect of supercritical drying conditions in ethanol on the structural and textural properties of silica aerogels, J. of Porous Mater., 2008, Vol.15, pp.705-713.

[30] DAVIS,P.J., BRINKER,C.J., SMITH,D.M.: Pore structure evolution in silica gel during aging/drying I. Temporal and thermal aging, J. Non-Cryst. Solids, 1992, Vol.142, pp.189-196.

[31] SCHWERTFEGER,F., FRANK,D., SCHMIDTM.: Hydrophobic waterglass based aerogels without solvent exchange or supercritical drying, J. Non-Cryst. Solids, 1998, Vol.225, pp.24-29.

[32] PRAKASH, S.S., BRINKER, C.J., HURD, A.J, RAO, S.M.: Silica aerogel films prepared at ambient pressure by using surface derivatization to induce reversible drying shrinkage, Nature, 1995., Vol.374, pp.439-442.

[33] GURAV,J.L., JUNG,I.K., PARK,H.H., KANG,E.S., NADARGI,D.Y.: Silica aerogel: synthesis and applications, J. of Nanomat., 2010, Vol.2010, pp.1-11.

[34] TABATA, M., ADACHI, I., ISHII, Y., KAWAI, H., SUMIYOSHI, T., YOKOGAWA, H.: Development of transparent silica aerogel over a wide range of densities, Nuclear Instruments and Methods in Physics Research Section A: Accelerators, Spectrometers, Detectors and Associated Equipment, 2010, Vol.623, pp.339-341.

[35] GURAV,J., RAO,A., NADARGI,D., PARK,H.H., Ambient pressure dried TEOS-based silica aerogels: good absorbents of organic liquids, J. of Mater. Sci. 2010, Vol. 45, pp. 503-510.

[36] DUTOIT,D.C.M., SCHNEIDER,M., BAIKER,A.: Titania-Silica Mixed Oxides: I. Influence of Sol-Gel and Drying Conditions on Structural Properties, J. of Catal. 1995, Vol.153 (1), pp.165-176.

[37] ARAVIND,P. R., SHAJESH,P., MUKUNDAN,K., WARRIER,G. K.:: Silica-titania aerogel monoliths with large pore volume and surface area by ambient pressure drying, J. of Sol-Gel Sci. and Techn., 2009, Vol.52 (3), pp.328-334.

[38] FENECH,J., VIAZZI,C., BONINO,J.P., ANSART,F., BARNABE,A.: Morphology and structure of YSZ powders: comparison between xerogel and aerogel, Cer. Intern., 2009, Vol.35, pp.3427-3433.

[39] ZHANG,Y., CAO,J., NIE,D., YANG,C., CHEN,X., ZHAO,L., LIU,Y.: Effect of preparation condition on pore structure of $\mathrm{SiO}_{2}$-aerogel, Rare Met. Mat. and Eng., 2009, Vol.38, pp.350-353.

[40] GARCÍA-GONZÁLEZ, C.A., CAMINO-REY, M.C., ALNAIEF, M., ZETZL, C., SMIRNOVA, I.: Supercritical drying of aerogels using CO2: effect of extraction time on the endmaterial textural properties, J. of Sup. Flu., 2012., Vol.66, pp.297-306.

[41] TAJIRI,K., IGARASHI,K., NISHIO,T.: Effects of supercritical drying media on structure and properties of silica aerogel, J. of Non-Crystal. Solids, 1995, Vol.186, pp.83-87.

[42] CALVINO, J.J., CAUQUI, J M.A, GATICA, M., PEREZ, J.A., RODRIGUEZ-IZQUIERDO, J.M.: Development of Acidity on Sol-Gel Prepared TiO2-SiO2 Catalysts, Mater. Res. Soc. Proc., 1994., Vol.346, p.685.

[43] BRODSKY,C.J., KO,E.I.: Effect of drying temperature on the physical properties of titania aerogels, J. Mater. Chem., 1994, 4, p 651.

[44] BRODSKY,C.J., KO,E.I.: Effect of supercritical drying temperature on the properties of zirconia, niobia and titania-silica aerogels, J. Non-Cryst. Solids, 1995., Vol.186, pp.88-95.

[45] GONTIER,S., TUEL,A.: Synthesis and characterization of Ticontaining mesoporous silicas, Zeolites, 1995, Vol.15, pp. 601-610.

[46] STOJANOVIC,D., ORLOVIC,A., GLISIC,S.B., MARKOVIC,S., RADMILOVIC,V., USKOKOVIC,P.S., ALEKSIC,R.: Preparation of MEMO silane-coated $\mathrm{SiO}_{2}$ nanoparticles under high pressure of carbon dioxide and ethanol, J. of Supercritical Fluids, 2010, Vol.52 (3), pp.276-284. 
[47] ĆOSOVIĆ,A.R., ŽÁK,T., GLISIC,S.B., SOKIĆ,M.D., LAZAREVIĆ,S.S., ĆOSOVIĆ,V.R., ORLOVIĆ,A.M.: Synthesis of nano-crystalline $\mathrm{NiFe}_{2} \mathrm{O}_{4}$ powders in subcritical and supercritical ethanol, J. of Supercritical Fluids, 2016, Vol.113, pp.96-105.

[48] STOJANOVIĆ,D.B., BRAJOVIĆ,L., ORLOVIĆ,A., DRAMLIĆ,D., RADMILOVIC, V., USKOKOVIC, P.S., ALEKSIC, R.: Transparent PMMA/silica nanocomposites containing silica nanoparticles coating under supercritical conditions, Prog. in Org. Coat., 2013, Vol.76 (4), pp.626-631.

[49] DAMYANOVA,S., DIMITROV,L., MARISCAL,R., FIERRO,J.L.G., PETROV,L., SOBRADOS,I.: Immobilization of 12molybdophosphoric and 12-tungstophosphoric acids on metalsubstituted hexagonal mesoporous silica, Appl. Catal. A: Gen., 2003, Vol.256, pp.183-197.

[50] GAO,X., WACHS,I.E.: Titania-silica as catalysts: molecular structural characteristics and physico-chemical properties, Catal. Today, 1999, Vol.51, pp.233-254.

[51] SCHRAML-MARTH,M., WALTHER,K.L.,WOKAUN,A., HANDY, B.E., BAJKER,A.: Porous silica gels and $\mathrm{TiO}_{2} / \mathrm{SiO}_{2}$ mixed oxides prepared via the sol-gel process: characterization by spectroscopic techniques, J. Non-Cryst. Solids, 1992, Vol.143, pp.93-111.
[52] DURAN,A., SERNA,C., FORNES,V., FERNANDEZ-NAVARRO, J.M.: Structural considerations about $\mathrm{SiO}_{2}$ glasses prepared by sol-gel, J. Non-Cryst. Solids, 1986, Vol.82, pp.69-77.

[53] BOCCUTI,M.R., RAO,K.M., ZECCHINA,A., LEOFANTI,G.P.: Structure and reactivity of surfaces, Stud. Surf. Sci. Catal., 1989, Vol.48, p.133.

[54] ZEPEDA,T.A., HALACHEV,T., PAWELEC,B., NAVA,R., KLIMOVA,T., $\quad$ FUENTES,G.A., $\quad$ FIERRO,J.L.G.: Hydrodesulfurization of dibenzotiophene over CoMo/HMS and CoMo/Ti-HMS catalysts, Catal. Commun., 2006, Vol.7, pp.3-41.

[55] ALIBOURI,M., GHOREISHI,S.M., AGHABOZORG, Hydrodesulfurization of dibenzothiophene using CoMo/Al-HMS nanocatalyst synthesized by supercritical deposition, J. of Supercritical Fluids 2009, Vol.49, pp. 239-248.

[56] ESTELLA,J., ECHEVERRIA,J.C., LAGUNA,M.: Effect of supercritical drying conditions in ethanol on the structural and textural properties of silica aerogels, J Porous Mater, 2008, 15:705-713.

Received: 10.01.2017. Accepted: 20.03.2017.

\title{
Uticaj sušenja u višku natkritičnog rastvarača na teksturalne karakteristike nosača katalizatora Ti-HMS
}

\begin{abstract}
Teksturalne karakteristike katalizatora i nosača katalizatora su od izuzetne važnosti kad je u pitanju korišćenje katalizatora u procesima u kojima učestvuju jedinjenja velike molekulske mase. Način sušenja vlažnog gela igra značajnu ulogu u očuvanju njegovih karakteristika. Heksagonalna mezoporozna silika (HMS) sa jonima titanijuma sve se vise koristi kao nosač heterogenih katalizatora. U ovom radu je predstavljen uticaj sušenja u višku rastvarača u natkritičnim uslovima na teksturalne karakteristike Ti-HMS. HMS sa jonima Ti (Si/Ti atomskog odnosa 40) sintetisana je primenom sol-gel metode. Kao templejt za formiranje struktura korišćen je dodecilamin $\left(\mathrm{S}^{\circ}\right)$, a kao neorganski prekursori $\left(I^{\circ}\right)$ tetraetilortosilikat (TEOS) i titanijum butoksid. Upoređene su specifična površina, mezoporoznost i zapremina pora nosača sušenog termičkom evaporacijom rastvarača u vazduhu i nosača sušenog u višku natkritičnog etanola. Rezultati pokazuju da je korišćenjem natkritičnog sušenja poboljšana vrednost specifične površine nosača i dobijena četiri puta veća vrednost zapremine mezopora.
\end{abstract}

Ključne reči: katalizatori, mezoporozni katalizatori, sol-gel postupak, sušenje, frakcije nafte.

\section{Воздействие сушки в избытке сверхкритического растворителя на текстурные характеристики носителя катализатора Ti-HMS}

\begin{abstract}
Текстурные характеристики катализатора и носителя катализатора имеют большое значение, когда речь идёт об использовании катализаторов в процессах с участием высокомолекулярных соединений. Метод сушки влажного геля играет важную роль в сохранении его характеристик. Шестиугольный мезопористый силикон (HMS) с ионами титана всё чаще используется в качестве носителя гетерогенных катализаторов. В настоящей работе представлено влияние сушки над растворителями (в избытке) в условиях сверхкритических напряжений на текстурные характеристики Ti-HMS. HMS с ионами Ti (Si / Ti атомное соотношение 40) синтезировали с использованием сольгель-метода. В качестве матрицы для образования структур использовали додециламин $\left(\mathrm{S}^{\circ}\right)$ и в качестве неорганических предшественников $\left(I^{\circ}\right)$ - тетраэтилортосиликат (TEOS) и бутоксид титана. Сравнивали удельную площадь поверхности, мезопористость и объём пор носителя, высушенного путём термического испарения растворителя в воздухе, и носителя, высушенного в избытке сверхкритического этанола. Результаты показывают, что использование сверхкритической сушки улучшает значение удельной поверхности носителя и даёт в четыре раза бо́льшую величину объёма мезопора.
\end{abstract}




\title{
Influence du séchage dans l'excès du solvant supercritique sur les caractéristiques texturales du support de catalyseur Ti-HMS
}

\begin{abstract}
Les caractéristiques texturales des catalyseurs sont de première importance pour l'utilisation des catalyseurs dans les processus où participent les unités de grande masse moléculaire. Le mode du séchage du gel humide joue un rôle important dans la préservation de ses caractéristiques. Le silice hexagonal méso poreux (HMS) avec les ions de titane est de plus en plus utilisé comme le support des catalyseurs hétérogènes. Dans ce papier on a présenté l'influence du séchage dans l'excès du solvant dans les conditions supercritiques sur les caractéristiques texturales Ti-HMS. Le HMS aux Ti -ions ( $\mathrm{Si}$ / Ti de ration atomique 40) a été synthétisé à l'aide da la méthode sol - gel. Le dodécyclamine ( $\left.\mathrm{S}^{\circ}\right)$ a été employé pour former les structures et TEOS et titane butoxide comme les précurseurs inorganiques. On a comparé la surface spécifique, la méso porosité et le volume des pores du support par l'évaporation du solvant dans l'air et le support séché dans l'excès de l'éthanol supercritique. Les résultats démontrent que la valeur de surface spécifique du support a été améliorée et on a obtenu la valeur du volume des méso pores quatre fois plus grande.
\end{abstract}

Mots clés: catalyseurs, catalyseurs méso poreux , procédé sol - gel, séchage, fractions de pétrole. 